TEME, г. XLIII, бр. 3, јул - септембар 2019, стр. 661-679

Прегледни рад

https://doi.org/10.22190/TEME190403041B

Примљено: 3. 4. 2019.

UDK 502.131.1:620.9(497.11)

Ревидирана верзија: 17. 10. 2019.

Одобрено за штампу: 20. 10. 2019.

\title{
ОДРЖИВИ РАЗВОЈ ЕНЕРГЕТИКЕ У РЕПУБЛИЦИ СРБИЈИ
}

\author{
Никола Бошковић", Данијела Деспотовић, Лела Ристић \\ Универзитет у Крагујевцу, Економски факултет, Крагујевац, Србија \\ nikolab@kg.ac.rs
}

\begin{abstract}
Апстракт
У раду је анализиран развој енергетског сектора на подручју Републике Србије у претходном периоду, који је показао одређене економске и неекономске недостатке, који не могу бити дугорочно прихватљиви. Савремени економски развој намеће бројне изазове које треба решити да би се обезбедила дугорочна одрживост енергетског сектора, који је један од кључних покретача развоја националних економија. Ти изазови су последица дејства бројних фактора, од којих су доминантни улога коју енергетски сектор има у развоју националних економи$\mathrm{ja}, \mathrm{c}$ једне стране, али и све веће експлоатације необновљивих енергетских ресурса и загађења животне средине, које настаје убрзаним, неконтролисаним развојем енергетике заснованој на коришћењу претходно поменуте групе ресурса, с друге стране. У прилог томе, неопходно је успоставити тзв. одрживи развој енергетике на подручју Републике Србије, који ће обезбедити истовремено задовољење економских, еколошких, социјалних и других циљева одрживог развоја. Одрживи развој енергетике Републике Србије мора да иде у правцу интензивнијег коришћења обновљивих извора енергије и повећања енергетске ефикасности како би се задовољила растућа тражња за енергетским производима. То је истовремено и институционална обавеза коју је Република Србија прихватила у погледу усклађивања сопственог енергетског сектора са истим у земљама ЕУ, у контексту европских интеграција. Да би се наведено обезбедило, потребно је диверзификовати понуду енергетских ресурса и обезбедити сигурност у погледу снабдевања финалним енергетским производима привреде и становништва, уз контролисано смањење емисије штетних гасова. Тако успостављен концепт развоја енергетике је једино дугорочно могућ и одржив.
\end{abstract}

Кључне речи: одрживи развој, енергетика, енергетска ефикасност, обновљиви извори енергије, Република Србија. 


\title{
SUSTAINABLE DEVELOPMENT OF ENERGY SECTOR IN THE REPUBLIC OF SERBIA
}

\begin{abstract}
This paper analyzes the development of the energy sector in the Republic of Serbia in the previous period, which has exhibited certain economic and non-economic disadvantages that are unacceptable in the long-term. Modern economic development raises a number of challenges to be addressed in order to ensure long-term sustainability of the energy sector as one of the key drivers of the national economy. These challenges are the result of numerous factors, the most influential being the role the energy sector plays in the development of the national economy, on the one hand, and growing use of nonrenewable energy resources and environmental pollution caused by rapid and uncontrolled development of energy sector based on exploitation of the aforementioned group of resources, on the other hand. In addition, it is necessary to implement sustainable energy development in the Republic of Serbia to secure meeting of economic, environmental, social and other sustainable development goals. It is imperative that development of energy sector moves forwards the more intensive use of renewable energy sources and increase energy efficiency in order to meet the growing demand for energy products. Within the framework of the EU accession process, and in line with the harmonization requirements with the EU acquis pertaining to the energy sector, the Republic of Serbia has also committed to achieve sustainable development of its energy sector and systems. In order to be able to implement the above stated, it is necessary to diversify the offer of energy resources and to provide secure energy supply, i.e., the supply of final energy products to industry and households, at the same time respecting the objectives of a controlled reduction of greenhouse gas emissions. The only possible long-term and sustainable concept of energy development is the concept designed in this manner.
\end{abstract}

Key words: $\quad$ sustainable development, energy sector, energy efficiency, renewable energy sources, Republic of Serbia.

\section{УВОДНА РАЗМАТРАҢА}

Одрживи развој као термин је глобалну препознатљивост добио након Конференције УН у Стокхолму 1972. године, када је њиме описана зависност између економског развоја, квалитета окружења и социјалне једнакости. Највећи утицај на иницијалну популаризацију и институционализацију појма „одрживи развој” имао је Извештај Светске комисије за животну средину и развој из 1987. године - Our Common Future, тзв. Брундтланд извештај. Тада је проистекла и прва дефиниција одрживог развоја, која подразумева „развој који омогућава задовољење потреба садашњих генерација, без угрожавања потреба будућих генерација" (Brundtland, 1987, p. 37). Кључни допринос успостављања одрживог развоја огледа се у потреби интеграције економског развоја и окружења у којем се он остварује, у смислу да економски развој не може дугорочно да постоји уколико се наруши квалитет ресурсне базе; окружење не може да буде заштићено, док развој не може да покрије трошкове нарушавања окружења. Све то јасно указује да одрживи развој постаје мул- 
тидимензионални концепт, који балансира економске, еколошке и социјалне димензије развоја и постаје својеврсни изазов модерног доба (Cirstea et al., 2018, p. 811). Имајући у виду да су проблеми са којима се сусреће савремени економски развој све више међународног карактера, у последње две деценије било је доста покушаја на глобалном нивоу да се институционализује одрживи развој и да се дефинишу његови циљеви. Кључни документи донети у овом периоду, почевши од горе поменутог Brundtland Report (1987), преко Rio Earth Summit (1992), Millenium Declarations (2000) и Rio+20 (2012), резултирали су у тзв. Агенди 2030, која је у септембру 2015. године донета на заседању Генералне скупштине УН. Поменути документ садржи 17 циљева одрживог развоја (SDGs) и 169 повезаних циљева, који треба да буду остварени у периоду до 2030. године (UN, 2015).

Имајући у виду значај који наведени документ има за Републику Србију, у раду ће бити доминантно анализиран циљ који се тиче успостављања одрживог развоја енергетике - циљ 7: Осигурати приступ материјално приступачној, поузданој, одрживој и модерној енергији за све. То директно резултира у потреби успостављања тзв. чистије енергетике, тј. развој еколошки прихватљиве енергетике, која је ослоњена на интензивније коришћење обновљивих извора енергије и повећање енергетске ефикасности.

Како Република Србија има своја стратешка опредељења ка ЕУ, која су још 2006. године резултирала њеним чланством у Енергетској заједници земаља Југоисточне Европе, као првој интеграцији која је била формирана у складу са принципима и под директним утицајем ЕУ, развој енергетике је у претходних 12 година био у највећем делу ослоњен на принципе који су успостављени од стране ЕУ. У складу са наведеним, у раду ће бити анализирано кретање индикатора одрживог развоја енергетике Републике Србије које прописује ЕУ, а који би требало да доведу до остваривања претходно дефинисаних циљева.

У складу са претходно наведеним, предмет истраживања у овом раду је одрживи развој енергетике у Републици Србији. Циљ истраживања је да се утврди да ли је и у ком степену у Републици Србији остварен одрживи развој енергетике и на који начин треба усмеравати даљи развој енергетике у складу са усвојеним глобалним циљевима, пре свега оним у Агенди 2030. У раду се полази од следеће хипотезе: Уколико се развој енергетике у Републици Србији правилно усмерава и развија на одрживим основама, могу се очекивати вишеструки позитивни друштвено-економски ефекти. У раду су коришћене квалитативне и квантитативне методе истраживања примерене друштвеним наукама, односно, истраживањима у области економије: историјски метод, метод индукције и дедукције, анализе и синтезе, компарације, дескрипције, статистички метод и метод генерализације. 
664

\section{ПРЕГЛЕД ЛИТЕРАТУРЕ}

Енергетика представља једну од најзначајнијих привредних грана и делатности. Савремени економски развој захтева не само довољну количину укупне енергије него и одређену структуру, која треба да одговара достигнутом нивоу организационог, техничко-технолошког и економског развоја, као и еколошким захтевима, што се потпуно уклапа у концепт одрживог развоја (Миленковић \& Бошковић, 2011, стр. 299).

Улога и значај енергетике у савременом развоју проистичу и из чињенице да је светска производња енергетских извора вишеструко већа од производње било које друге врсте производа (Мандал \& Михајловић-Милановић, 2010, стр. 98).

Литература из области одрживог развоја енергетике можда је и најбројнија из читавог спектра одрживог развоја, из једноставног разлога, јер енергетика својим функционисањем највише угрожава животну средину и изазива глобалне климатске промене (Kissinger, Rees \& Timmer, 2011). То се јасно види и из података УН, према којима енергетика утиче на емитовање $60 \%$ гасова са ефектом стаклене баште (UN, 2015). Такође, енергетика исцрпљује огромну количину необновљивих природних ресурса. Поред тога што исцрпљује необновљиве ресурсе, енергетика њиховом прерадом и употребом може да угрози равнотежу у природном окружењу и тиме да поништи позитивне ефекте на економски развој и да потпуно угрози остварење концепта одрживог развоја (Кокеза, 2017, стр. 175).

Циљеви одрживог развоја енергетике су бројни, хетерогени, често међусобно супростављени и тешко интегрално оствариви (Слика 1).

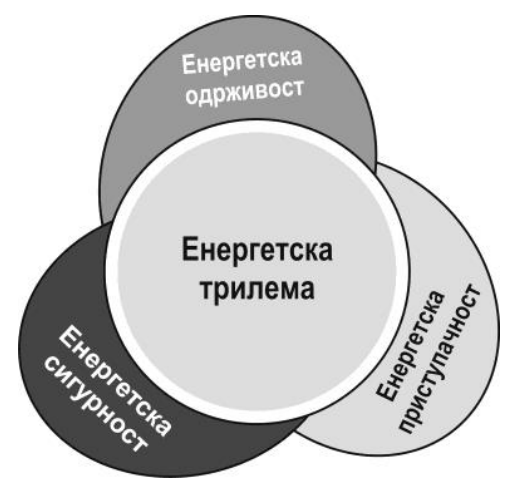

Слика 1. Енергетска трилема Извор: Roddis et al., 2016.

Енергетика мора да обезбеди очување природних ресурса, као и да омогући контролу приступа ресурсима, све у циљу обезбеђења си- 
гурности снабдевања енергетским производима. То снабдевање мора да буде у складу са основним циљевима макроекономске политике државе, као и да буде у складу са очувањем животне средине (OECD, 2005, p. 3). Из претходно наведеног може се закључити да енергетика има доста сложене захтеве у погледу свог развоја. Они су доста изазовни и у последње две деценије су фундаментално изменили читав концепт развоја енергетике, у смислу већег ослањања на обновљиве енергетске ресурсе и побољшање енергетске ефикасности. Ове димензије одрживог развоја енергетике анализиране су од стране бројних аутора, како на глобалном (Neves \& Leal, 2010) тако и на нивоу Републике Србије (Karakosta, Flouri, Dimopoulou \& Psarras, 2012; Tešić, Kiss, \& Zavargo, 2011).

Аутори Перовић и Радукић (2017, стр. 761), анализирајући економску, еколошку и социјалну димензију одрживог развоја у Републици Србији и земљама окружења, недвосмислено су дошли до закључка да је еколошка димензија, мерена преко ЕРI индикатора, најпроблематичнија компонента одрживог развоја. Слични резултати су остварени и у анализама развоја енергетике на глобалном нивоу (UN, 2015; EU, 2018), што јасно опредељује основни правац одрживог развоја енергетике: смањење загађења животне средине, односно, смањење коришћења фосилних горива, уз све више ослањање на обновљиве енергетске ресурсе. Технолошка компонента одрживог развоја енергетике је све значајнија (Musago \& Brent, 2011), jep је неопходно извршити побољшање технолошких процеса трансформације једног облика енергије у други. Да би такве промене у енергетском сектору постале реалне и дугорочно одрживе, неопходна је институционална подршка државе и референтних међународних институција у правцу стимулисања интензивнијег коришћења обновљивих енергетских ресурса. Мазур је у свом истраживању (Mazur, 2011) покушао да направи паралелу између растуће потрошње енергије и квалитета живота у економски развијеним земљама. Таква зависност је могућа само до одређеног нивоа потрошње енергије, након тога долази до пада квалитета живота, који је последица прекомереног загађења животне средине.

Анализирајући бројна схватања одрживог развоја оних привредних грана које су доминантно засноване на природним ресурсима, а енергетика је свакако једна од њих, најзначајнија су она која под одрживим развојем енергетике подразумевају: очување производних могућности, у смислу да било корисност, било ниво потрошње током времена не опадају (Solow, 1986); стање по којем се енергетски ресурси експлоатишу на такав начин да доносе одрживи прираст или одрживи принос (Harris, 2006), али и такав развој који обезбеђује минимум стабилности еколошких популација током времена (Perman, Ma, Mc Gilvray \& Common, 1999). Оваква схватања 
подразумевају да, поред економских, морају да буду заступљена и еколошка питања, што у потпуности одговара претходно наведеним циљевима одрживог развоја енергетике.

Светски савет за енергетику (WEC, 2018) дефинисао је циљеве одрживог развоја енергетике: приступачност, расположивост и прихватљивост (Слика 2).

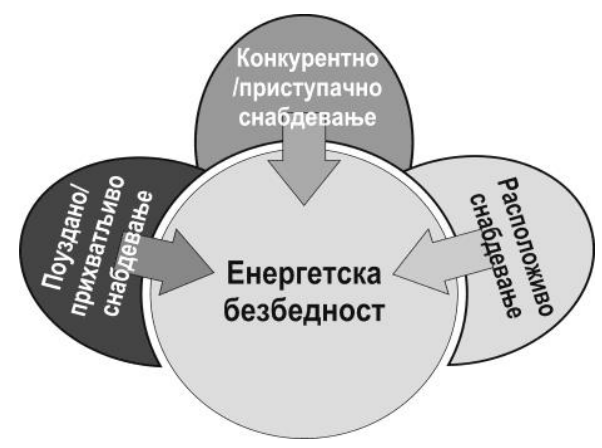

Слика 2. Дефинисање енергетске безбедности Извор: WEC, 2018.

Приступачност енергије подразумева да енергија мора бити доступна по ценама које су прихватљиве за сиромашне људе и њену одрживост у смислу цене која омогућава производњу енергије, њену трансформацију и дистрибуцију и која даје основу за развој и одржавање енергетских система. Расположивост је повезана са континуираним снабдевањем енергијом у дужем временском периоду, као и квалитетом услуга. Прихватљивост подразумева усклађеност економског развоја и заштите животне средине.

Литература из области одрживог развоја енергетике подразумева коришћење бројних индикатора (Vera \& Langlois, 2007). Читав комплекс индикатора развила је група аутора (Patlitzianas, Doukas, Kagiannas \& Psarras, 2008) у циљу давања конкретних смерница у правцу развоја одрживе енергетике. Анализирајући индикаторе који су донети на нивоу појединих земаља (Тsai, 2010; Shortall \& Davidsdottir, 2017; Oh, Hasanuzzaman, Selvaraj, Teo \& Chua, 2018), може се јасно закључити да не постоји једна усаглашеност на глобалном нивоу. Како је предмет анализе рада Република Србија, сматрамо да је примена индикатора коју примењују земље чланице ЕУ најприхватљивија (Михајлов, 2010; García-Álvarez, Moreno \& Soares, 2016).

Сумирајући теоријска схватања о одрживом развоју енергетике, неопходно је истаћи основне смернице, које су дате у оквиру глобалних циљева одрживог развоја. Као што је претходно истакнуто, циљ 7: Осигурати приступ материјално приступачној, поузданој, одрживој и модерној енергији за све - директно усмерава будући развој 
енергетике на глобалном нивоу до 2030. године у следећим правцима (UN, 2015):

1. Обезбедити универзални приступ јефтиним, поузданим и модерним енергетским услугама;

2. Значајно повећати удео обновљиве енергије у глобалном енергетском миксу;

3. Удвостручити глобалну стопу побољшања енергетске ефикасности;

4. Унапредити међународну сарадњу како би се олакшао приступ истраживању и технологији; чисте енергије, укључујући обновљиву енергију, енергетску ефикасност и напредну и чистију технологију фосилних горива, и промовисати инвестирање у енергетску инфраструктуру и технологију чисте енергије, и

5. Проширити инфраструктуру и унапредити технологију за снабдевање модерном и одрживом енергијом за све у земљама у развоју, а посебно у најмање развијеним земљама и малим острвским државама у развоју, државама у развоју које немају излаз на море, у складу са њиховим програмима подршке.

Наведене смернице прихватила је и Република Србија и оне представљају јасни оквир у ком правцу ће се кретати развој енергетике у периоду до 2030. године.

\section{МЕТОДОЛОГИЈА}

Истраживање одрживог развоја енергетике засновано је на коришћењу више научних метода примењивих у пољу друштвенохуманистичких наука, односно, у истраживањима из области економије. Сагласно дефинисаном проблемском подручју у раду, а у циљу тестирања полазне хипотезе, коришћене су квалитативне и квантитативне методе истраживања. Сврха примене историјског метода је утврђивање фактора који су у ранијим развојним фазама утицали на развој енергетике, јер је то битно за детерминисање њених будућих праваца развоја. Анализиран је развој коришћења обновљивих и необновљивих енергетских ресурса, појединачно, али и у њиховом међусобном садејству, у смислу могућности супституције необновљивих обновљивим, што је препорука концепта одрживог развоја, па су у раду коришћени метод индукције и дедукције, као и анализе и синтезе.

Природа истраживаног проблема захтевала је да се у раду користе дескриптивни, компаративни и статистички метод за представљање кључних показатеља развоја енергетике у Републици Србији. 
668

\section{РЕЗУЛТАТИ ИСТРАЖИВАЬА}

Основне карактеристике развоја енергетике на подручју Републике Србије

Енергетски сектор Републике Србије је доста хетероген, у највећој мери је усклађен са земљама у окружењу и у процесу је усклађивања са истим у ЕУ. Он обухвата: сектор нафте; сектор природног гаса; сектор угља; електроенергетски сектор; сектор топлотне енергије; сектор индустријске енергетике и сектор обновљивих извора енергије (Бањац, Рамић, Лилић \& Пантић, 2015, 14-15).

Структуру енергетског сектора, његову диверзификованост и степен развоја појединих сегмената условила је превасходно ресурсна расположивост, тј. енергетски ресурсни потенцијал. У Табели 1 приказан је ресурсни потенцијал обе категорије енергетских ресурса.

Табела 1. Енергетски ресурсни потенщијал у Републици Србији

\begin{tabular}{|c|c|c|}
\hline $\begin{array}{l}\text { Врста необновљивог } \\
\text { енергетског ресурса }\end{array}$ & $\begin{array}{c}\text { Енергетска вредност } \\
\text { геолошких резерви, } \\
\text { y Mtoe } \\
\end{array}$ & $\begin{array}{c}\text { Учешће у укупним } \\
\text { резервама необновљивих } \\
\text { ресурса, у \% }\end{array}$ \\
\hline 1. Угаљ & 3.940 & 88,78 \\
\hline 2. Уљни шкриљци & 398 & 8,97 \\
\hline 3. Природни гас & 50 & 1,13 \\
\hline 4. Нафта & 50 & 1,13 \\
\hline $\begin{array}{l}\text { Укупан расположиви } \\
\text { енергетски потенцијал } \\
\text { необновљивих ресурса } \\
\end{array}$ & 4.438 & 100,00 \\
\hline $\begin{array}{l}\text { Врста обновљивог } \\
\text { енергетског ресурса }\end{array}$ & $\begin{array}{c}\text { Енергетска вредност } \\
\text { резерви на годишњем } \\
\text { нивоу, у Mtoe } \\
\end{array}$ & $\begin{array}{c}\text { Учешће у укупним } \\
\text { резервама обновљивих } \\
\text { ресурса, у \% } \\
\end{array}$ \\
\hline Биомаса & 3,448 & 61,03 \\
\hline Водни ресурси & 1,679 & 29,72 \\
\hline Ветар & 0,103 & 1,82 \\
\hline Сунце & 0,240 & 4,25 \\
\hline Геотермални & 0,180 & 3,18 \\
\hline $\begin{array}{l}\text { Укупан годишњи } \\
\text { енергетски потенцијал } \\
\text { обновљивих ресурса }\end{array}$ & 5,650 & 100,00 \\
\hline
\end{tabular}

Извор: Аутори, на основу: Влада Републике Србије, 2015, стр. 3-4, 6-7.

Ресурсни потенцијал необновљивих енергетских ресурса у Републици Србији је такав да доминира угаљ са учешћем од $88,78 \%$ у структури резерви необновљивих ресурса. Резерве нафте и природног гаса учествују са $1,13 \%$, што је, имајући у виду степен њиховог коришћења, доста скромно. Ова два облика енергетских ресурса су и главна увозна компонента, што је један од изазова у процесу будућег одрживог развоја енергетике у Републици Србији. Једно од 
тих решења огледа се и у коришћењу уљних шкриљаца, који имају сасвим респектабилан ресурсни потенцијал (398 Mtoe) и учешће од 9\% у структури резерви необновљивих енергетских ресурса.

Што се тиче нивоа и структуре ресурсног потенцијала обновљивих извора енергије, он износи око 5,65 Мtoе годишње. Највећи ресурсни потенцијал имају биомаса $(3,448$ Mtoe) и водни ресурси (1,679 Mtoe), са укупним учешћем од преко 90\% у потенцијалу свих обновљивих извора. Остали обновљиви извори енергије имају знатно мањи потенцијал, који износи укупно око 0,5 Mtoe (График 1).

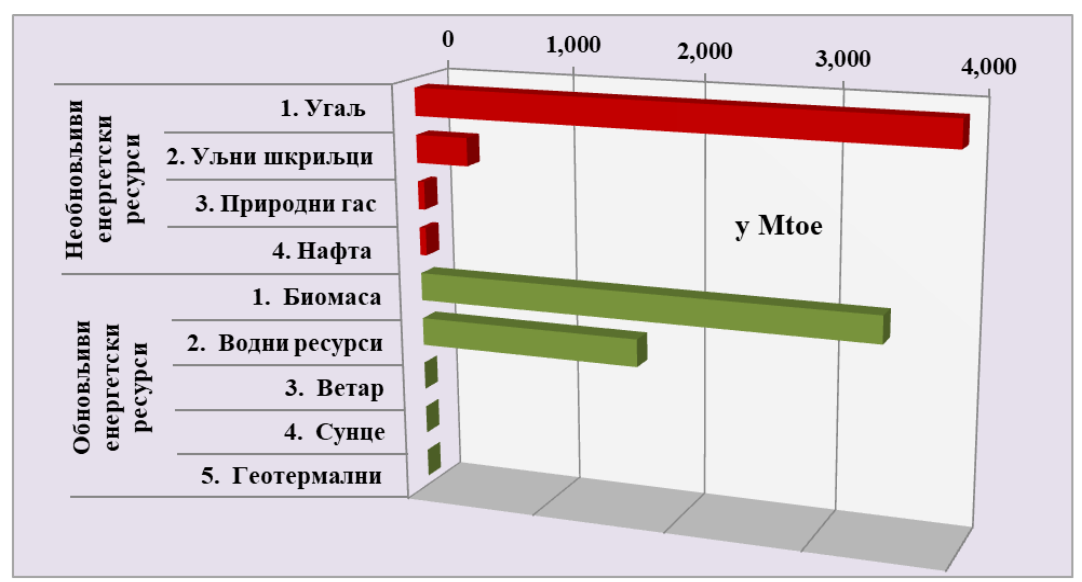

График 1. Енергетски ресурсни потениијал у Републищи Србији Извор: Аутори на основу података из Табеле 1

Претходно изложен енергетски ресурсни потенцијал условио је и структуру енергетског биланса Републике Србије у периоду 2000-2017. године (Табела 2).

Из наведеног приказа можемо извући одређене карактеристике развоја енергетике Републике Србије у претходно анализираном периоду (2000-2017. године):

- Производња примарне енергије бележи растућу тенденцију у првом анализираном периоду (2000-2004. године), затим значајан пад у наредном четворогодишњем периоду, да би након 2008. године била релативно константна. Посебно је са становишта одрживог развоја енергетике значајан пораст коришћења обновљивих извора енергије, који је скоро удвостручен у анализираном периоду.

- Нето увоз показује доста различите вредности у анализираним периодима и превасходно је резултат кретања увоза нафте и природног гаса. Индикативан је значајнији пад у периоду 2008-2012. године (као последица пада економских 
активности изазваних светском економском кризом), да би уз економски опоравак и интензивиран, пре свега, индустријски развој у Републици Србији, у периоду након 2012. године дошло до пораста увоза, пре свега природног гаса и нафте.

- Обим укупно расположиве енергије (који представља збир претходно поменутих категорија) бележи пад у периоду 2004-2012. године, да би након 2012. године дошло до пораста, превасходно као последица пораста увоза.

Табела 2. Енергетски биланс Републике Србије за период 2000-2017. године, у Мtoе

\begin{tabular}{lrrrrrr}
\hline & 2000. & 2004. & 2008. & 2012. & 2016. & 2017. \\
\hline $\begin{array}{l}\text { Производња примарне } \\
\text { енергије }\end{array}$ & $\mathbf{1 1 , 8 2 8}$ & $\mathbf{1 2 , 0 0 2}$ & $\mathbf{1 0 , 7 1 3}$ & $\mathbf{1 0 , 7 5 8}$ & $\mathbf{1 0 , 6 4 5}$ & $\mathbf{1 0 , 5 2 5}$ \\
\hline Угаљ & 8,351 & 9,300 & 8,224 & 7,278 & 7,201 & 7,216 \\
Нафта & 0,952 & 0,586 & 0,639 & 1,194 & 0,978 & 0,977 \\
Природни гас & 0,623 & 0,257 & 0,214 & 0,425 & 0,417 & 0,433 \\
Обновљиви ресурси & 1,091 & 1,859 & 1,635 & 1,861 & 2,049 & 1,899 \\
\hline Нето увоз & $\mathbf{1 , 8 8 1}$ & $\mathbf{5 , 6 7 8}$ & $\mathbf{5 , 9 8 7}$ & $\mathbf{3 , 7 8 8}$ & $\mathbf{4 , 6 6 2}$ & $\mathbf{5 , 4 8 2}$ \\
\hline Угаљ & 0,305 & 0,548 & 0,728 & 0,340 & 0,783 & 0,670 \\
Нафта & 0,475 & 3,200 & 3,467 & 2,170 & 2,718 & 2,837 \\
Природни гас & 0,910 & 2,057 & 1,788 & 1,233 & 1,474 & 1,931 \\
Електрична енергија & 0,259 & $-0,023$ & 0,006 & 0,033 & $-0,165$ & 0,071 \\
\hline Укупно расположива & $\mathbf{1 3 , 7 0 9}$ & $\mathbf{1 7 , 6 8 0}$ & $\mathbf{1 6 , 7 0 0}$ & $\mathbf{1 4 , 5 4 6}$ & $\mathbf{1 5 , 3 0 7}$ & $\mathbf{1 5 , 9 3 1}$ \\
енергија & & & & & & \\
\hline Угаљ & 8,656 & 9,848 & 8,952 & 7,628 & 7,884 & 7,875 \\
Нафта & 1,427 & 3,786 & 4,106 & 3,364 & 3,696 & 3,751 \\
Природни гас & 1,533 & 2,312 & 2,002 & 1,678 & 1,891 & 2,352 \\
Обновљиви ресурси & 1,834 & 1,759 & 1,635 & 1,843 & 2,001 & 1,931 \\
Електрична енергија & 0,259 & $-0,023$ & 0,006 & 0,033 & $-0,165$ & 0,071 \\
\hline Енергија расположива & $\mathbf{7 , 1 1 5}$ & $\mathbf{1 0 , 6 8 3}$ & $\mathbf{9 , 8 9 2}$ & $\mathbf{8 , 6 5 5}$ & $\mathbf{9 , 2 9 0}$ & $\mathbf{9 , 5 9 9}$ \\
за финалну потрошњу & & & & & & \\
\hline Финална неенергетска & 0,242 & 0,428 & 0,943 & 0,331 & 0,851 & 0,833 \\
потрошња & & & & & & \\
Финална потрошња за & 6,941 & 10,330 & 9,478 & 8,486 & 8,603 & 8,697 \\
енергетске сврхе & & & & & & \\
Индустрија & 2,172 & 3,498 & 3,155 & 2,486 & 2,486 & 2,437 \\
Саобраћај & 0,825 & 2,159 & 2,400 & 1,847 & 2,149 & 2,194 \\
Домаћинства & 3,127 & 3,121 & 3,222 & 3,135 & 2,941 & 2,965 \\
Пољопривреда & 0,129 & 0,145 & 0,086 & 0,184 & 0,192 & 0,198 \\
Остало & 0,688 & 1,407 & 0,615 & 0,834 & 0,835 & 0,903 \\
\hline
\end{tabular}

Извор: Аутори, на основу Eurostat, 2018; Влада Републике Србије, 2018.

Претходно наведене тенденције могуће је графички представити (График 2). 


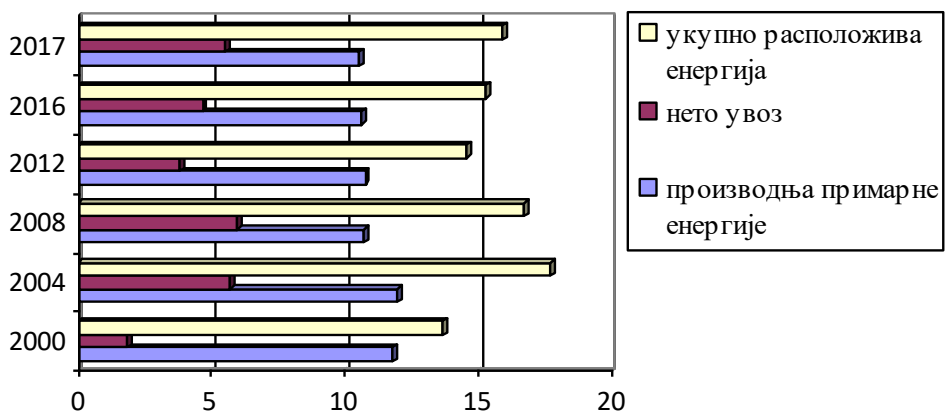

График 2. Кретање основних енергетских показатељь Извор: Аутори на основу података из Табеле 2.

Из представљеног енергетског биланса могу се извући још два битна закључка развоја енергетике у Републици Србији у претходном периоду.

Прво, степен енергетске трансформације примарне енергије у финалну представља први индикатор ефикасности енергетског система, посматран као однос енергије расположиве за потрошњу и укупно расположиве енергије, на подручју Републике Србије бележи у периоду након 2004. године релативно константне вредности (око 0,600$)$, што је испод просека ЕУ, који износи 0,734 (Eurostat, 2018). Повећањем трансформације примарне у финалну енергију значајно би се смањило коришћење енергетских ресурса и тиме унапредио одрживи развој енергетике.

Друго, потрошња финалне енергије показује доста неповољну структуру. Према подацима из 2017. године, доминантна је потрошња у сектору домаћинства (око 34\%), затим сектору индустрије (28\%) и сектору транспорта (24\%). У ЕУ структура је обрнута: доминира потрошња у сектору транспорта, сектору индустрије, па у сектору домаћинства, с тим да је учешће у пољопривреди двоструко веће (Eurostat, 2018). Претходно наведено могуће је графички представити (График 3).

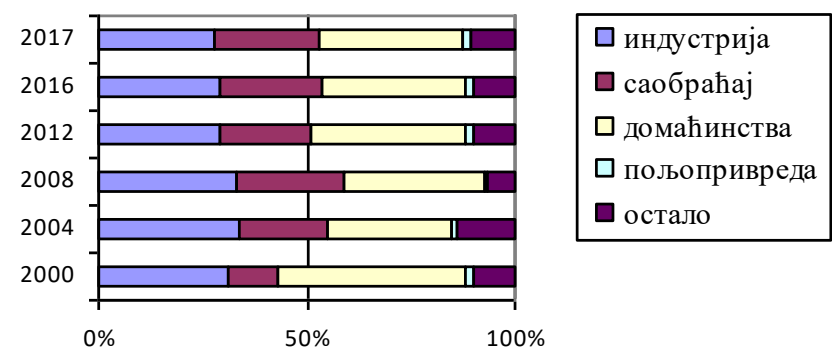

График 3. Структура потрошње енергије по секторима у Републици Србији

Извор: Аутори на основу података из Табеле 2. 
Са становишта одрживог развоја, сасвим је исправно да доминира потрошња у секторима који су означени као производни (индустрија, саобраћај, пољопривреда), јер у том случају енергетика и финални енергетски производи доприносе економском развоју. У прилог томе, у Републици Србији би требало стимулисати интензивније коришћење енергетских производа у горе поменутим секторима.

Кључни показатељи одрживог развоја енергетике у Републици Србији

Анализирајући тенденције кретања приказаних у енергетском билансу Републике Србије, могуће је дати анализу основних енергетских индикатора (Табела 3 ).

Табела 3. Најважнији индикатори енергетског сектора Републике Србије

\begin{tabular}{|c|c|c|c|c|c|c|}
\hline Индикатор & 2000. & 2004. & 2008. & 2012. & 2016. & 2017. \\
\hline $\begin{array}{l}\text { Потрошња енергије по становнику, } \\
\text { y toe }\end{array}$ & 1,7 & 2,2 & 2,3 & 2,0 & 2,2 & 2,2 \\
\hline $\begin{array}{l}\text { Потрошња електричне енергије по } \\
\text { становнику, у MWh }\end{array}$ & 3,9 & 3,9 & 4,3 & 4,4 & 4,6 & 4,7 \\
\hline Енергетска интензивност, у toe $/ 1000 \$$ & 0,5 & 0,5 & 0,4 & 0,4 & 0,4 & 0,4 \\
\hline $\begin{array}{l}\text { Учешће обновљивих ресурса у укупној } \\
\text { производњи енергије, у \% }\end{array}$ & 16 & 15 & 15 & 17 & 19 & 17 \\
\hline $\begin{array}{l}\text { Учешће обновљивих ресурса у укупној } \\
\text { потрошњи енергије, у \% }\end{array}$ & 13 & 10 & 10 & 13 & 13 & 12 \\
\hline $\begin{array}{l}\text { Учешће обновљивих ресурса у } \\
\text { производњи електричне енергије, у \% }\end{array}$ & 35 & 30 & 26 & 26 & 28 & 27 \\
\hline Увозна зависност, у \% & 14 & 32 & 36 & 26 & 30 & 34 \\
\hline
\end{tabular}

У Републици Србији дошло је до пораста потрошње финалне енергије по становнику (са 1,7 на 2,2 toe) као последица пораста животног стандарда у претходном периоду (мерено преко раста GDPa), што није прихватљиво са аспекта одрживог развоја енергетике, чији је један од циљева смањење потрошње енергије по становнику.

Повезано са претходним, индикатор потрошње појединих облика финалне енергије по становнику је, такође, често коришћен у анализи енергетских ресурса. Из претходне табеле јасно се закључује да потрошња електричне енергије, као једног од најважнијих енергетских производа, по становнику у Републици Србији бележи растуће тенденције.

Претходно наведени индикатори не дају праву слику о улози коју енергетика има у економском развоју. Због тога је крајем прошлог века уведен индикатор који показује потрошњу енергетских ресурса по јединици друштвеног производа. Овај индикатор истовремено показује и ефикасност коришћења енергетских ресурса. 
По правилу, што је земља економски развијенија, то је и вредност овог индикатора нижа. У прилог претходно наведеном, кретање овог индикатора у Републици Србији, у анализираном периоду, бележи повећање ефикасности коришћења енергетских ресурса за око $20 \%$ (са 0,6 на 0,5). То је само делимично прихватљиво са становишта одрживог развоја енергетике, имајући у виду да је у земљама ЕУ вредност овог индикатора 0,11 (IEA, 2019), што показује да је у ЕУ коришћење енергетских ресурса пет пута ефикасније него у Србији. У наредним периодима, да би се унапредио одрживи развој енергетике у Републици Србији, неопходно је интензивирати повећање енергетске ефикасности (даљи пад наведеног индикатора).

Увозна зависност (изузимајући податке за 2000. годину) показује релативно константне вредности и одговара ресурсној расположивости, пре свега, нафте и природног гаса.

Смањење увозне зависности једино је могуће повећањем енергетске ефикасности или интензивирањем коришћења обновљивих енергетских ресурса.

Група индикатора која је везана за коришћење обновљивих енергетских ресурса (учешће обновљивих ресурса у укупној производњи енергије, учешће обновљивих ресурса у укупној потрошњи енергије и учешће обновљивих ресурса у производњи електричне енергије) показује да у претходних 17 година није дошло до позитивних трендова у погледу коришћења обновљивих енергетских ресурса.

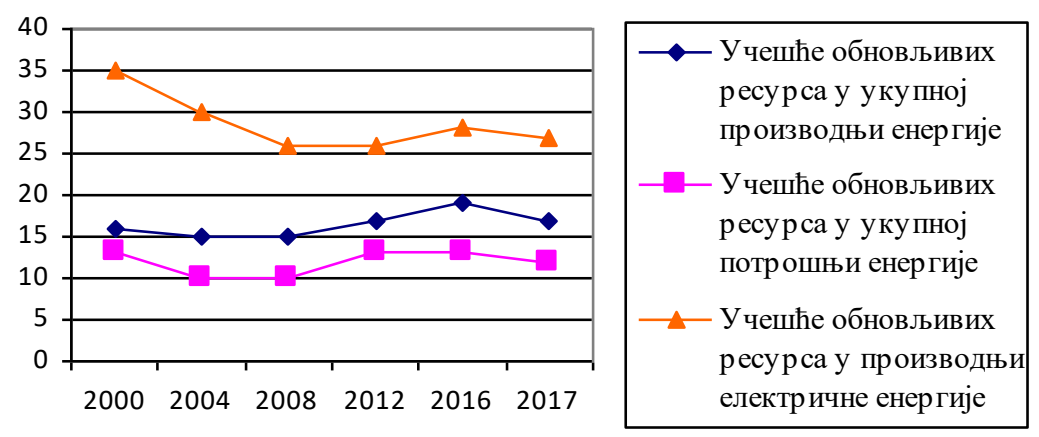

График 4. Кретање учешћа обновљьвих извора енергије у Републищи Србији

Извор: Аутори на основу података из Табеле 3.

Као што се јасно закључује из Графика 4 , сви анализирани индикатори бележе негативна кретања, у смислу да долази до пада или стагнације обновљивих ресурса. То свакако није прихватљиво са аспекта одрживог развоја енергетике, јер је управо повећање учешћа обновљивих ресурса један од кључних циљева одрживог развоја. 
Синтетизујући највећи број индикатора одрживог развоја енергетике, у складу са дефинисаним глобалним циљевима одрживог развоја, Светска банка је од 2010. године развила Регулаторни индикатор одрживог развоја енергетике (RISE). Овај синтетички енергетски индекс односи се на национални ниво и показује у којој мери конкретна држава подстиче одрживи развој енергетике. Сви подстицаји су груписани у три хомогене целине (World Bank, 2018a):

1. Доступност енергији, у смислу у ком обиму држава подстиче развој енергетске инфраструктуре и који проценат становништва има приступ финалним облицима енергије;

2. Обновљиви извори, који обухватају, пре свега, подстицаје у интензивнијем коришћењу обновљивих извора енергије, али и у којој мери су еколошки прописи имплементирани и у ком степену обавезујући у енергетском систему земље;

3. Енергетска ефикасност, која подразумева развој националних институционалних и других законских решења, у правцу повећања ефикасности коришћења енергетских производа.

Према методологији коју примењује Светска банка, RISE индекс има вредност од 0 до 100, при чему је вредност ближа броју 100 одрживија и прихватљивија са становништа одрживог развоја енергетике. Вредности су класификоване у три зоне (World Bank, 2018a, p. 7):

1. Зелена зона, која обухвата вредности од 67 до 100 и која означава да држава јасно подстиче одрживи развој енергетике;

2. Жута зона, која укључује вредности од 34 до 66 и која подразумева значајан допринос одрживом развоју енергетике;

3. Црвена зона, која обухвата вредности од 0 до 33 и која подразумева да држава својим мерама економске политике не подстиче одрживи развој енергетике.

У Табели 4 приказане су вредности RISE индикатора у Peпублици Србији у периоду 2010-2017. године.

Табела 4. Вредности RISE индикатора у Републици Србији у периоду 2010-2017. године

\begin{tabular}{|c|c|c|c|c|c|}
\hline \multirow[b]{2}{*}{ Година } & \multicolumn{3}{|c|}{ Вредност подиндекса } & \multirow[b]{2}{*}{$\begin{array}{c}\text { RISE } \\
\text { укупно }\end{array}$} & \multirow[b]{2}{*}{ Зона } \\
\hline & $\begin{array}{c}\text { Доступност } \\
\text { енергији }\end{array}$ & $\begin{array}{c}\text { Обновљиви } \\
\text { извори }\end{array}$ & $\begin{array}{l}\text { Енергетска } \\
\text { ефикасност }\end{array}$ & & \\
\hline 2010. & 100 & 22 & 14 & 45 & жута \\
\hline 2011. & 100 & 22 & 15 & 46 & жута \\
\hline 2012. & 100 & 36 & 16 & 51 & жута \\
\hline 2013. & 100 & 47 & 41 & 63 & жута \\
\hline 2014. & 100 & 50 & 41 & 64 & жута \\
\hline 2015. & 100 & 50 & 46 & 66 & жута \\
\hline 2016. & 100 & 53 & 60 & 71 & зелена \\
\hline 2017. & 100 & 53 & 66 & 73 & зелена \\
\hline
\end{tabular}

Извор: Аутори, на основу World Bank, 20186. 
У периоду 2010-2017. године остварен је значајан напредак у подстицању одрживог развоја енергетике посматран кроз RISE индекс. Наиме, вредност индекса је увећана са 45 на 73, на основу чега закључујемо да Република Србија подстиче одрживи развој енергетике.

Анализирајући поједине сегменте RISE индекса, долазимо до следећих закључака:

- Доступност енергији у свим посматраним годинама има максималну вредност (100), што показује да је енергетска инфраструктура довољно развијена;

- Обновљиви извори енергије бележе растуће вредности (са 22 на 53), али недовољно, имајући у виду бројне сегменте, нарочито који се тичу имплементирања еколошких прописа;

- Енергетска ефикасност остварује значајан напредак у анализираном периоду (са 14 на 66). У наредним фазама неопходно је смањивати потрошњу финалне енергије у сектору домаћинстава и на тај начин даље повећавати енергетску ефикасност.

Прихватајући најважније европске смернице у погледу коришћења обновљивих енергетских ресурса (European Commission, 2001), Peпублика Србија у својим стратешким енергетским документима уводи категорију повлашћених произвођача електричне, односно, топлотне енергије, који користе обновљиве енергетске ресурсе за производњу енергије (Влада Републике Србије, 2015).

Најважнија карактеристика повлашћених произвођача је приоритетан статус који имају на организованом тржишту енергије у односу на друге произвођаче. Они имају право на субвенције, пореске, царинске и друге олакшице, које су неопходне за профитабилност производње електричне енергије на бази обновљивих енергетских ресурса.

Табела 5. Подстицајне тарифе за различите типове електрана y Републичи Србији, у еврочентима по KWh

\begin{tabular}{lcc}
\hline Тип електране & $\begin{array}{c}\text { Инсталисана снага } \\
(\mathrm{MW})\end{array}$ & $\begin{array}{c}\text { Подстицајна тарифа } \\
\text { (евроцент/KWh) }\end{array}$ \\
\hline Нове хидроелектране & $<0,5$ & 9,7 \\
& $0,5-2$ & 10,3 \\
& $2-10$ & 7,85 \\
\hline Постојеће хидроелектране & $<2$ & 7,35 \\
& $2-10$ & 5,9 \\
\hline Електране на биомасу & $<0,2$ & 16,0 \\
& $0,2-2$ & 16,4 \\
& $>2$ & 12,7 \\
\hline Ветроелектране & & 9,3 \\
Соларне електране & & 23,0 \\
Геотермалне електране & \multicolumn{2}{c}{ Извор: Аутори, на основу: Влада Републике Србије, 2016. }
\end{tabular}

Извор: Аутори, на основу: Влада Републике Србије, 2016. 
Из Табеле 5 уочава се да су подстицајне тарифе постављене за све облике обновљивих енергетских ресурса којима Република Сpбија располаже, што је институционално добро постављена мера.

Резултати који су остварени у претходним периодима нису показали ефекте наведених мера, па самим тим нису довели ни до одрживог развоја енергетике у Републици Србији. Њиховим спровођењем и даљим усклађивањем са енергетским тржиштима земаља у окружењу и у оквиру ЕУ очекује се интензивније коришћење обновљивих извора, као и повећање ефикасности коришћења финалних енергетских производа, што би требало да доведе до одрживог развоја енергетике.

\section{ЗАКЉУЧНА РАЗМАТРАЬА}

Одрживи развој енергетике је један од основних изазова свих националних економија. То проистиче из потребе усклађивања економских система и последица по окружење у смислу загађења, које настаје неконтролисаним коришћењем енергетских ресурса и развојем оних сегмената енергетике који доводе до нарушавања животне средине и појаве глобалних климатских промена. Бројни глобални институционални покушаји решавања наведених проблема резултирали су променама енергетике у многим земљама, у смислу преоријентације на интензивније коришћење обновљивих енергетских ресурса.

Енергетски сектор у Републици Србији у претходним периодима није усклађен са принципима одрживог развоја. Релативно висока и растућа потрошња финалне енергије по становнику, као и пет пута већа потрошња по јединици БДП-а у односу на земље ЕУ главна су ограничења енергетског сектора. Такође, релативно високо учешће сектора домаћинстава у укупној потрошњи финалне енергије свакако представља један од важних изазова унапређења енергетике у будућем периоду.

Претходне анализе јасно су показале да је кључни изазов одрживог развоја енергетике у Републици Србији повећање енергетске ефикасности (смањење потрошње енергије по јединици друштвеног производа) и повећање коришћења обновљивих енергетских ресурса. Ова два циља међусобно су повезана и једино интегралним приступом могуће је побољшати енергетске перформансе Републике Србије.

Да би се обновљиви енергетски ресурси интензивније користили за добијање финалних енергетских производа, потребно је да буду ценовно конкурентни необновљивим. То је једино могуће уз одговарајућу институционалну подршку државе. Дакле, држава својим мерама економске политике треба да смањи разлику која постоји између цене коришћења обновљивих и необновљивих енергетских pecyрса. То се може постићи укључивањем екстерних трошкова у 
структуру укупних трошкова, што значи да еколошка загађења која настају експлоатацијом необновљивих енергетских ресурса (угља, нафте и природног гаса) буду додата основним трошковима и на тај начин да се они учине мање атрактивним за експлоатацију. Други начин је директна или индиректна подршка изградњи капацитета на бази коришћења обновљивих енергетских ресурса.

\section{ЛИТЕРАТУРА}

Banjac, M., Ramić, B., Lilić, D., \& Pantić, A. (2015). Energija u Srbiji 2013 [Energy in Serbia 2013]. Beograd: Ministarstvo rudarstva i energetike.

Brundtland, G. (1987). Our Common Future: Report of the World Commission on Sustainable Development. Geneva: United Nations.

Cirstea, S. D., Moldovan-Teselios, C., Cîrstea, A., Turcu, A. C., \& Darab, C. P. (2018). Evaluating Renewable Energy Sustainability by Composite Index. Sustainability, 10(3), 811-830.

EU. Sustainable development in the European Union. (2018). Retrieved from https://ec.europa.eu/eurostat/documents/3217494/9237449/KS-01-18-656-ENN.pdf/2b2a096b-3bd6-4939-8ef3-11cfc14b9329 (15.01.2019).

European Commission. Directive 2001/77/EC of 27 September 2001 on the promotion of electricity produced from renewable energies sources in the internal electricity market. (2001). Retrieved from www.ec.europa.eu/energy (21.02.2019).

Eurostat. Energy Balances in the MS Excel file format. (2018). Retrieved from https://ec.europa.eu/eurostat/web/energy/data/energy-balances (21.01.2019).

García-Álvarez, M., Moreno, B., \& Soares, I. (2016). Analyzing the sustainable energy development in the EU-15 by an aggregated synthetic index. Ecological Indicator, 60, 996-1007.

Harris, J. (2006). Environmental and Natural Resource Economics. New York: Houghton.

IEA. Country profile. (2019). Retrieved from http://www.iea.org/countries/ (15.04.2019).

Karakosta, C., Flouri, M., Dimopoulou, S., \& Psarras, J. (2012). Analysis of renewable energy progress in the western Balkan countries: Bosnia-Hercegovina and Serbia. Renewable and Sustainable Energy Reviews, 16, 5166-5175.

Kissinger, M., Rees, W., \& Timmer, V. (2011). Interregional sustainability: governance and policy in an ecologically interdependent world. Environment Policy, 14(8), 965-976.

Kokeza, G. (2017). Strategijski pravci razvoja energetike i održivi rast privrede Srbije [Strategic directions of energy development and sustainable growth of Serbian economy]. Energija, ekonomija, ekologija, 19(1-2), 172-178.

Mandal, Š., \& Mihajlović-Milanović, Z. (2010). Ekonomika energetike [Energy Economics]. Beograd: Ekonomski fakultet.

Mazur, A. (2011). Does increasing energy or electricity consumption improve quality of life in industrial nations? Energy Policy, 39(5), 2568-2572.

Mihajlov A. (2010). Opportunities and challenges for a sustainable energy policy in SE Europe: SE European Energy Community Treaty. Renewable and Sustainable Energy Reviews, 14, 872-875.

Milenković, S., \& Bošković, N. (2011). Resursi u ekonomskoj sadašnjosti i budućnosti [Resources in the Economic Present and Future.]. Kragujevac: Ekonomski fakultet Univerziteta u Kragujevcu.

Musago, J., \& Brent, A. (2011). A conceptual framework for energy technology sustainability assessment. Energy for Sustainable Development, 15, 84-91. 
Neves, A., \& Leal, V. (2010). Energy sustainability indicators for local energy planning: Review of current practices and derivation of a new framework. Renewable Sustainable Energy Reviews, 14, 2723-2735.

OECD. Energy Prospects-An assessments of Long Term Energy Developments and Related policies. Paris: Organization for Economic Co-operation and Development. (2005).

Oh, T., Hasanuzzaman, M., Selvaraj, J., Teo, S., \& Chua, S. (2018). Energy policy and alternative energy in Malaysia: Issues and challanges for sustainable growth - An update. Renewable and Sustainable Energy Reviews, 81, 3021-3031.

Patlitzianas, K., Doukas, H., Kagiannas, A., \& Psarras J. (2008). Sustainable energy policy indicators: review and recommendations. Renew Energy, 33, 966-73.

Perman, R., Ma, Y., Mc Gilvray, J., \& Common, M. (1999). Natural Resource \& Environmental Economics. Harlow: Longman.

Perović, D., \& Radukić, S. (2017). Comparative analysis of sustainable development components for the Republic of Serbia and neighbouring countries. Teme, 41(3), 747-765.

Roddis, P., Gove, B., Morrison, A., Campbell, C., Beresford, A. E., Teuten, E., Dutton, A., \& Williams, L. J. (2016). The RSPB's 2050 energy vision: Meeting the UK's climate targets in harmony with nature. Bedfordshire, UK: RSPB.

Shortall, R., \& Davidsdottir, B. (2017). How to measure national energy sustainability performance: An Icelandic case-study. Energy for Sustainable Development, 39, 29-47.

Solow, R. (1986). On the Intergenerational Allocation of Natural Resources. Scandinavian Journal of Economics, 88(1), 141-149.

Tešić, M., Kiss, F., \& Zavargo, Z. (2011). Renewable energy policy in the Republic of Serbia. Renewable and Sustainable Energy Reviews, 15, 752-758.

Tsai, W. (2010). Energy sustainability from analysis of sustainable development indicators: A case study in Taiwan. Renewable and Sustainable Energy Reviews, 14, 2131-2138.

UN. Transforming Our World: The 2030 Agenda for Sustainable Development. New York: United Nations. (2015).

Vera, I., \& Langlois, L. (2007). Energy indicators for sustainable development. Energy, $32,875-82$

Vlada Republike Srbije. Odluka o utvrđivanju Energetskog bilansa Republike Srbije za 2019. godinu. „Službeni glasnik RS”, br. 105/18. (2018).

Vlada Republike Srbije. Strategija razvoja energetike Republike Srbije do 2025. godine sa projekcijama do 2030. godine. (2015).

Vlada Republike Srbije. Uredba o podsticajnim merama za proizvodnju električne energije iz obnovljivih izvora $i$ iz visokoefikasne kombinovane proizvodnje električne i toplotne energije. (2016).

WEC. World Energy Trilemma Index. London, UK: World Energy Council. (2018). Retrieved from https://www.worldenergy.org/wp-content/uploads/2018/10/ World-Energy-Trilemma-Index-2018.pdf (14.03.2019).

World Bank. Regulatory Indicators for Sustainable Energy 2018. (2018a). Retrieved from http://documents.worldbank.org/curated/en/553071544206394642/pdf/ 132782-replacement-PUBLIC-RiseReport-HighRes.pdf (16.03.2019).

World Bank. RISE Score, Serbia - Country profile. (2018b). Retrieved from http://rise. worldbank.org/scores (16. 3. 2019). 


\title{
SUSTAINABLE DEVELOPMENT OF ENERGY SECTOR IN THE REPUBLIC OF SERBIA
}

\author{
Nikola Bošković, Danijela Despotović, Lela Ristić \\ University of Kragujevac, Faculty of Economics, Kragujevac, Serbia
}

\begin{abstract}
Summary
The aim of this paper is to examine the development of the energy sector in the Republic of Serbia from the aspect of harmonization with sustainable development. Sustainable development of the energy sector is becoming one of the key determinants of the success of national economies. It is meant to provide the simultaneous fulfillment of the economic, environmental, social and other development goals. The challenges faced in the process of the energy systems development in the Republic of Serbia are multiple and diverse. They are, primarily, the direct consequence of the intensively used types of energy sources of which the coal, a non-renewable energy source, is predominantly used and thus, causes numerous problems in terms of achieving sustainable development. In addition, the high import dependence on oil and natural gas represents a major requirement for the future development of energy sector and systems on the territory of the Republic of Serbia, in terms of finding suitable alternatives and domestic energy resources to ensure energy security, safety and accessibility to domestic resources as one of the important features of sustainable energy development.

The paper analyzes in detail the possibility of switching to sustainable energy development, which would involve more intensive use of renewable energy sources and increased energy efficiency. There is a resource potential of renewable energy resources in the Republic of Serbia, and this is clearly presented in the paper. Therefore, the basic preconditions for sustainable energy development do exist. In what way and in what time such a development will be achieved depends largely on institutional support, which is essential in achieving the above-mentioned development goals.

Based on the analysis of energy indicators and their respective trends in the territory of the Republic of Serbia in the period after 2000, the paper concluded that the development of energy sector and its systems is not fully in line with the principles of sustainable development. This is confirmed by the analysis of RISE indicator, a comprehensive indicator developed by the World Bank. Positive trends relating to subindicators show that incentives for the use of renewable energy resources exist in the Republic of Serbia, but they are insufficient in terms of the share of renewables in total energy production and consumption, which is one of the key requirements of sustainable development. Although some improvements have been made in terms of encouraging energy efficiency, this has not significantly reduced the use of energy resources per unit of the social product, which is identified as the main problem in terms of sustainable energy development in the Republic of Serbia. In order to ensure energy efficiency, it is necessary to diversify the supply of energy resources and provide security in terms of supplying the final energy products both to the industry and population, at the same time implementing the measures for reduction of emissions of harmful gases. Such a concept of energy development is the only viable concept in terms of sustainability and in the long run. Further harmonization of energy development in the Republic of Serbia with objectives set out in numerous international documents implies more active support of the state, including further increase of energy efficiency and more intensive support to the use of renewable energy sources.
\end{abstract}

